\title{
1. INTRODUCTION AND PRINCIPAL RESULTS, LEG 34, DEEP SEA DRILLING PROJECT
}

\author{
Robert S. Yeats, Department of Geology, Ohio University, Athens, Ohio \\ and \\ Stanley R. Hart, Department of Terrestrial Magnetism, Carnegie Institution of Washington, \\ Washington, D.C.
}

\section{SCIENTIFIC GOALS}

Leg 34 was the first of two "basement" legs of the Deep Sea Drilling Project, in which a primary objective was deep drilling into oceanic basement. This objective was subordinate in previous legs, so that it was necessary to test and perfect the systems that are needed for deep penetration, especially reentry capabilities. A second objective was the investigation of the sediments of the Nazca plate, notable for its concentration of metalliferous sediments in the Bauer Deep. More specifically, the scientific goals were to determine the following:

1) Composition and structure of layer $2 \mathrm{~A}$ including the prevalence of pillow lavas versus fractured flows, thickness of individual flow units, and changes in composition and physical properties with depth and age.

2) Evidence for off-ridge volcanism and, if present, the difference between off-ridge and ridge volcanism.

3) Interaction between layer 2 and seawater in terms of seawater chemistry, weathering of basalts, and thickness of the weathered zone as a function of crustal age and thickness of overburden.

4) Magnetic properties of ocean-floor basalt as a clue to the nature of magnetic reversals and magnetic properties of sediments as a measure of plate motion.

5) Metalliferous sediments and their distribution as a function of time, sedimentation rate, and proximity to the rise crest.

6) Geologic history of the Nazca plate: abandonment of a "fossil rise" (Galapagos Rise) as a spreading center, and influence of the South American continent on Nazca plate sediments in terms of terrigenous and volcanic deposits and history of the Humboldt Current.

Operational constraints (the necessity of having about 80 meters of sediment cover to bury the bottom-hole assembly prior to reaching basalt) precluded drilling a hole on the East Pacific Rise crest, but we were able to drill Site 319 west of the Galapagos Rise crest in crust of Miocene age and Sites 320 and 321 east of the rise crest in crust of Oligocene and Eocene age, respectively.

Site 319 also permitted us to trace the history of metalliferous sedimentation in the Bauer Deep. Sites 320 and 321 investigated the early history of the Nazca plate in crust of different ages at the eastern edge, and also explored the early history of the Humboldt Current.

\section{OPERATIONAL SUMMARY}

Glomar Challenger departed Papeete, Tahiti, on 20 December 1973. After 16 days of steaming eastward, the first site (319) was reached in the Bauer Deep. Further eastward steaming took us to the final two sites (320 and
321) situated near the eastern edge of the Nazca plate just over $350 \mathrm{~km}$ from the coast of Peru. The cruise ended in Callao, Peru, on 2 February 1974. Figure 1 is a location map showing the ship's track and the major tectonic features of the Nazca plate. Table 1 gives the drilling and coring summary.

Deep basement penetration is contingent upon successful reentry into a hole to change bits. On Leg 34 , the setting of the reentry cone on bottom (keelhauling the cone under the ship, running casing through the cone, washing in the casing and cone on bottom, and releasing the drill string from the casing) was done at two sites (319 and 320) in a more or less routine manner, and this system may now be considered operational under good weather conditions. At Site 319, a mud-cross system was planned to be added to the cone to carry cuttings away from the cone on deep holes; however, the mud-cross proved to be unsatisfactory and subsequently was discarded because of the difficulty of running casing through it.

The principal difficulty in reentry was the performance of the EDO scanning tool, which at times failed under normal handling and would not rotate or scan properly in the hole. It is noteworthy that both reentries were successful despite the EDO problems which caused only a loss of rig time.

The heave compensator was used at Site 319, but not at sites 320 and 321 due to a malfunction. No improvement in core disturbance, basalt penetration rate, or bit life could be attributed to the heave compensator, but further testing is clearly indicated.

Figure 2 shows the total time distribution, and Figure 3 shows the on-site time distribution during Leg 34 . Nearly $50 \%$ of the total time was spent cruising, in part due to the slow speed of Glomar Challenger, which averaged 8.1 knots. Over $45 \%$ of the on-site time was spent in downtime, reentry, and problems with tight hole conditions. Some of this can be attributed to the learning process necessary for the reentry operations. In addition, there was considerable shakedown of reentry equipment such as the EDO scanning tool and the Schlumberger winch for running the scanning tool, and experimentation with new systems such as the mudcross. Finally, and perhaps most importantly, a considerable amount of time was spent fighting hole conditions.

\section{PRINCIPAL RESULTS IN BASEMENT DRILLING}

At Site 319, drilled on the west flank of the extinct Galapagos Rise in crust about 15 m.y. old, 59 meters of interlayered basalt flows and pillow lavas were penetrated. The thickest units, about 15 meters, are coarse- 
$90^{\circ}$

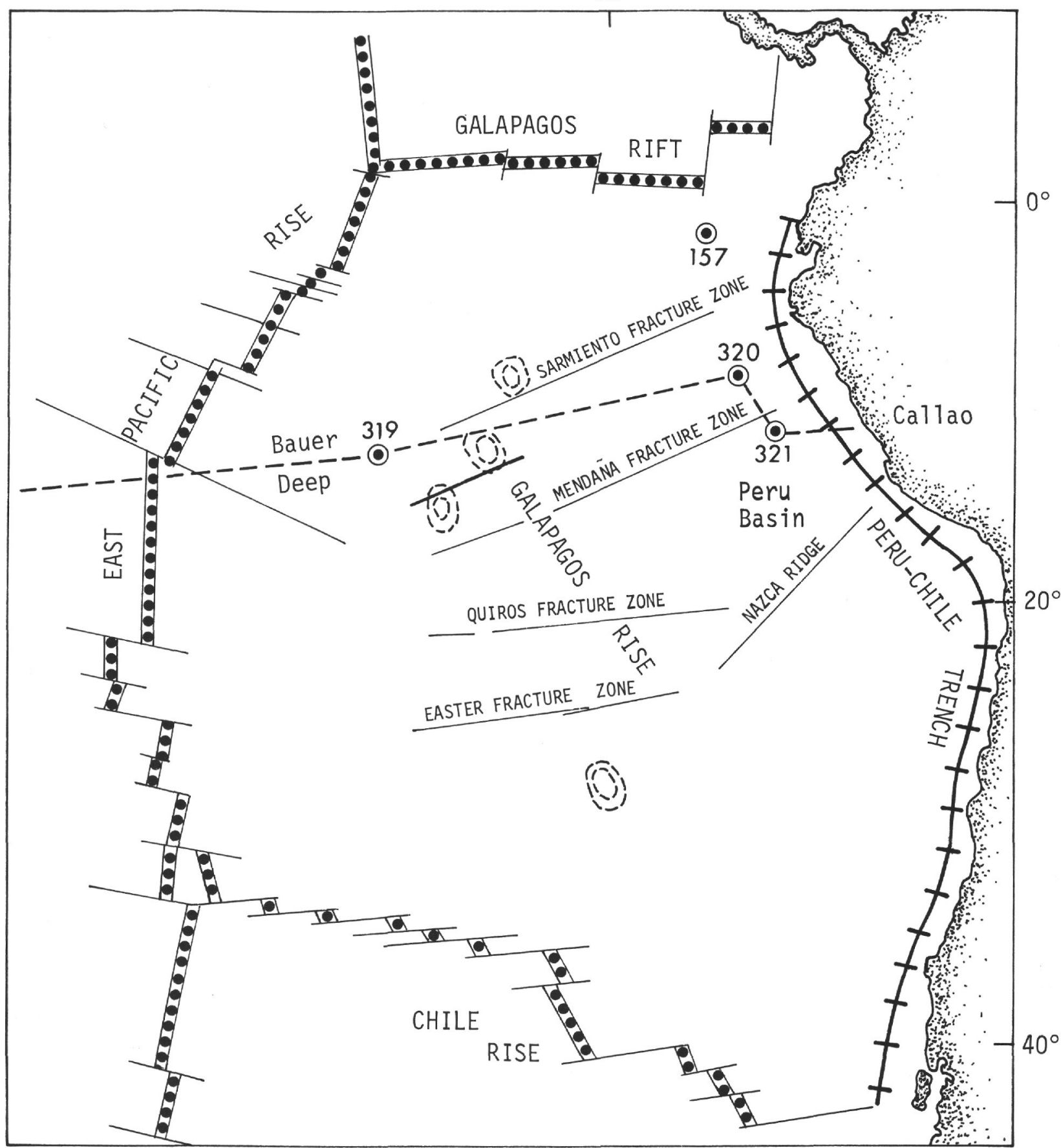

Toce Rise Crest

(i) Galapagos where known

- - Glomar Challenger Track

HH Trench Axis

\section{Fracture Zone}

Figure 1. Location map showing ship's track, sites drilled, and major tectonic features on the Nazca plate. 
TABLE 1

Drilling and Coring Summary, Leg 34

\begin{tabular}{|c|c|c|c|c|c|c|c|c|c|}
\hline Hole & $\begin{array}{l}\text { Dates } \\
(1974)\end{array}$ & $\begin{array}{l}\text { Latitude } \\
\text { (South) }\end{array}$ & $\begin{array}{l}\text { Longitude } \\
\text { (West) }\end{array}$ & $\begin{array}{c}\text { Water } \\
\text { Depth }(\mathrm{m})\end{array}$ & $\begin{array}{l}\text { Penetration } \\
\text { (m) }\end{array}$ & $\begin{array}{l}\text { No. of } \\
\text { Cores }\end{array}$ & $\begin{array}{l}\text { Cored } \\
\text { (m) }\end{array}$ & $\begin{array}{l}\text { Recovered } \\
\text { (m) }\end{array}$ & $\begin{array}{c}\text { Recovery } \\
(\%)\end{array}$ \\
\hline 319 & $\operatorname{Jan} 4-6$ & $13^{\circ} 01.04^{\prime}$ & $101^{\circ} 31.46^{\prime}$ & 4296 & 116.5 & 14 & 116.5 & 84.8 & 73 \\
\hline $319 \mathrm{~A}$ & Jan 9-16 & $13^{\circ} 01.04^{\prime}$ & $101^{\circ} 31.46^{\prime}$ & 4296 & 157.0 & 7 & 59.0 & 14.5 & 25 \\
\hline 320 & Jan $21-22$ & $9^{\circ} 00.40^{\prime}$ & $83^{\circ} 31.80^{\prime}$ & 4487 & 111.5 & 3 & 28.0 & 19.4 & 69 \\
\hline $320 \mathrm{~A}$ & Jan 22 & $9^{\circ} 00.40^{\prime}$ & $83^{\circ} 31.80^{\prime}$ & 4487 & 9.0 & 1 & 9.0 & 8.8 & 98 \\
\hline $320 \mathrm{~B}$ & Jan 23-28 & $9^{\circ} 00.40^{\prime}$ & $83^{\circ} 31.80^{\prime}$ & 4487 & 183.5 & 5 & 47.5 & 18.5 & 39 \\
\hline 321 & Jan 29-31 & $12^{\circ} 01.29^{\prime}$ & $81^{\circ} 54.24^{\prime}$ & 4827 & 134.5 & 14 & 125.0 & 85.8 & 61 \\
\hline Total & & & & & 712.0 & 44 & 385.0 & 231.8 & 60 \\
\hline
\end{tabular}

grained diabasic basalt containing phenocrysts of olivine and plagioclase with evidence of crystal settling in the lower parts of the flows. Olivine crystallization persists into the groundmass, a feature which is common in transitional or alkali basalt but unusual in typical spreading-ridge tholeiite. However, no alkali basalt was recovered during Leg 34 . Though the rock shows some signs of alteration, with groundmass and olivine being partly transformed to smectite, it is one of the freshest basalts yet recovered during the Deep Sea Drilling Project. The densities, sonic velocities, and water contents are all characteristic of essentially fresh basalt and show little variation with depth in the core. The relative freshness of these basalts is discussed in some detail by Hart (this volume). Although Site 319 was drilled in relatively young basement, the lack of alteration is not simply an age effect. Its basalts are significantly lower in water content than other drilled and dredged basalts of similar age $(0.7 \%$ versus about $2 \%)$.

At the third site (321), drilled on crust about 50 m.y. old, massive basalt flows are very similar to those at Site 319 in mineralogy, physical properties, and low degree of alteration. Because of the much greater age of crust at this third site ( 40 m.y. versus 15 m.y.), it may be that

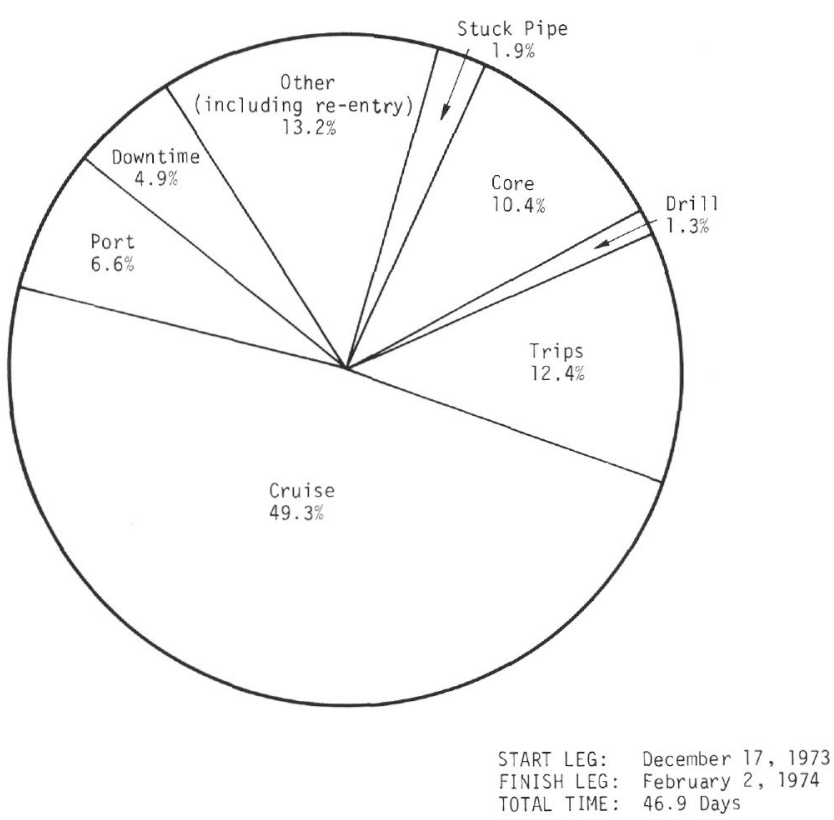

Figure 2. Total time distribution, Leg 34. some unusual circumstance has preserved these basalts from interaction with seawater.

In contrast to these two sites, at Site 320 we cored a series of pillow zones and thin flow units composed of fine-grained to glassy basalt with mineralogy typical of the olivine tholeiites of spreading ridges. The higher water content and lower densities and sonic velocities displayed by samples from this site suggest a greater degree of alteration, although still less than expected for rocks from crust of this age (30 m.y.). Furthermore, these properties change with depth, reaching almost unaltered values at the bottom of the core.

At all three sites, the basalts are cut by thin veins of carbonate, smectite, and sulfide. The origin of the materials in these veins is uncertain, but analysis of $\mathrm{Sr}$ isotope ratios in the carbonate and $\mathrm{Pb}$-isotope ratios in the sulfide may show whether the veins are deuteric or were produced by interaction with seawater. This is obviously an important question, as it may relate to the genesis of metalliferous sediments and the derivation of sulfide ores from the oceanic crust.

The natural remanent magnetism of the basalt and overlying sediment was measured at all three sites. Large

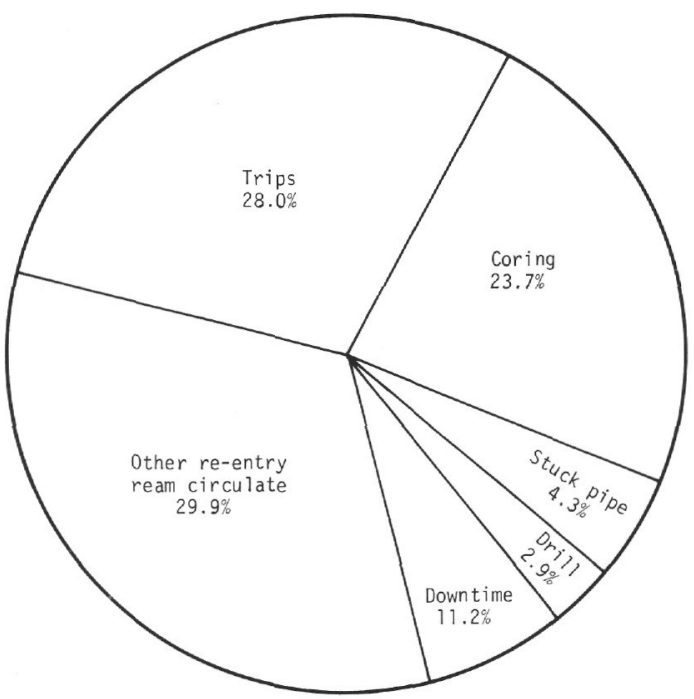

$$
\begin{array}{ll} 
& \\
\text { TOTAL TIME ON SITE: } & 20.7 \text { Days } \\
\text { TOTAL SITES: } & 3 \\
\text { TOTAL HOLES: } & 6
\end{array}
$$

Figure 3. On-site time distribution, Leg 34. 
Site 319

$\%$ METALLIFEROUS COMPONENTS

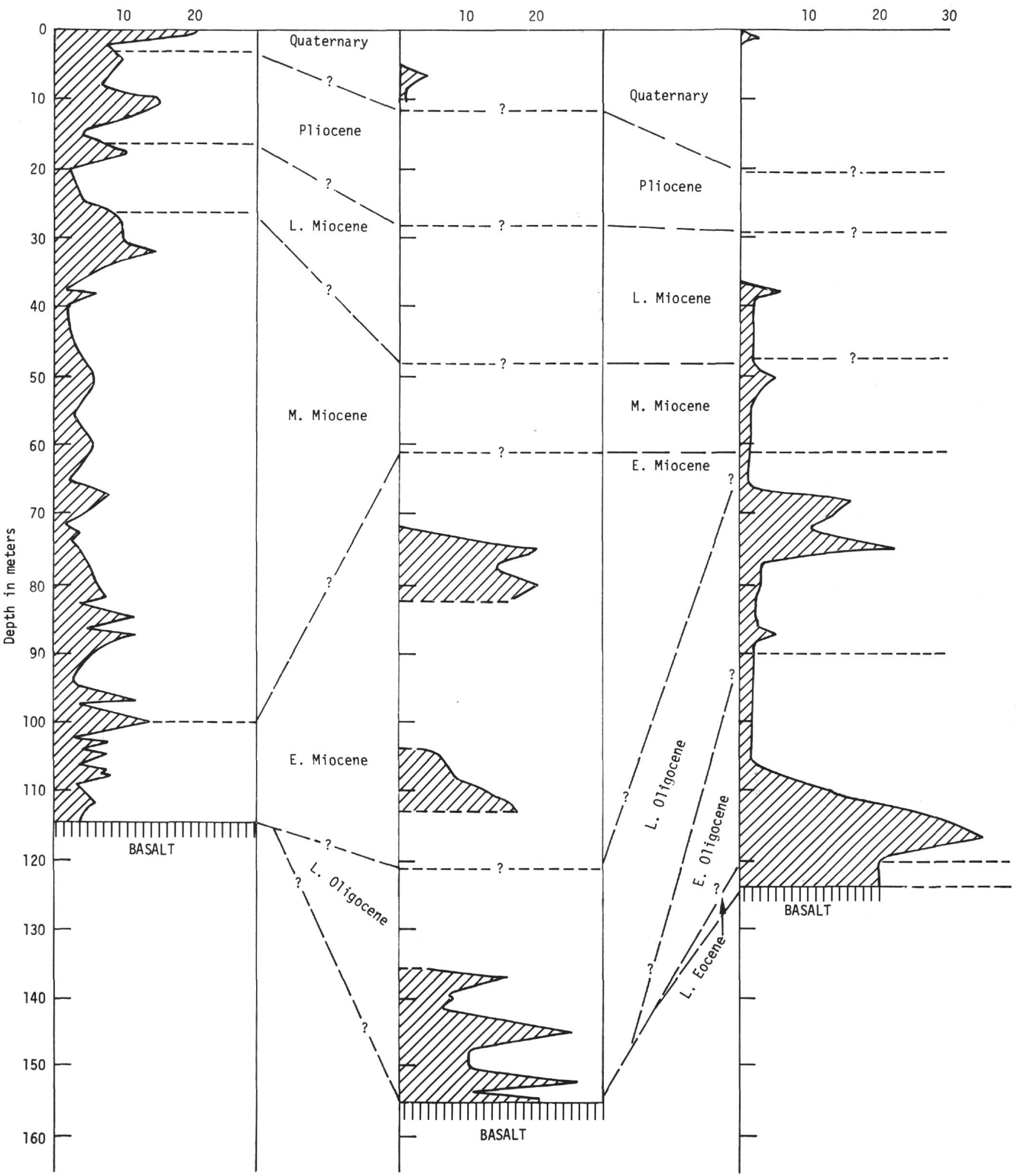

Figure 4. Comparison of visually estimated abundances of metalliferous components at the Leg 34 sites. Intervals with no data at Site 320 were not cored. 
latitudinal motions of the Nazca plate (and of the plates spreading from the extinct Galapagos Rise) over the past 15-40 m.y. would be indicated by NRM inclinations different from those to be expected at latitudes $10^{\circ}-13^{\circ} \mathrm{S}$. In sediments at all sites and in the basalts at all except Site 319, the inclinations are as expected for latitudes $10^{\circ}-13^{\circ} \mathrm{S}$ and suggest relatively little northsouth motion of the sites. The Site 319 basalts, with inclinations of $+57^{\circ}$, probably do not indicate plate motion but rather a short-time sampling of the geomagnetic field during a period of secular variation, as during a polarity transition. These results are consistent with the inferred eastward direction of absolute plate motion in this area. Another interesting aspect of the shipboard paleomagnetic measurements was the finding that the coarse-grained basalt flows had stronger paleomagnetic intensities than the fine-grained pillows and flow margins. This suggests that the intensity of the magnetic signature of the oceanic crust will depend on the local ratio of pillow to massive basalt in layer 2 .

One interesting aspect of the physical property measurements is that the range of sonic velocities measured for basalts from Sites 319, 320, and 321 (5.2$6.3 \mathrm{~km} / \mathrm{sec}$ at confining pressures appropriate to the sea floor) is considerably higher than the values of $4-5$ $\mathrm{km} / \mathrm{sec}$ normally reported for the upper 500-meter layer of the oceanic crust as derived from seismic-refraction profiles. Because seismic-refraction data have been the main basis for estimating the composition of the lower levels of the oceanic crust, this discrepancy clearly needs further study. The discrepancy is most likely a matter of scale; laboratory velocity measurements are usually done on small physically coherent samples, whereas the seismic-refraction data will average in some way all the fractures, void spaces, shear and breccia zones, unconsolidated pillow-lava zones, and interlayered sediments. This discrepancy may diminish at greater depth in the crust where there is sufficient load pressure to compact the various units or where pillow zones and interlayered sediments might be less common.

\section{PRINCIPAL RESULTS IN SEDIMENT DRILLING}

The general features of the sedimentary lithologies are given by Quilty et al. (this volume). Basically, the sections are represented by lower zones of nanno ooze overlain by clay sequences containing various other components-metalliferous components at Site 319, siliceous organisms at Site 320, and siliceous organisms plus volcanic glass and zeolite at Site 321 . The boundary between the lower nanno oozes and the upper clays is seen at all three sites as a reflector in the seismic profiles. This boundary occurs at somewhat different ages at the three sites, probably representing the time at which the site passed below the carbonate compensation depth as a result of crustal subsidence. Thus, the thickest section of nanno ooze at each site occurs at a lower stratigraphic level with increasing age of the basement: Site 319 (15 m.y.) contains a thick middle Miocene sec- tion, Site 320 (28 m.y.) a thick early Miocene section, and Site 321 (40 m.y.) a thick Oligocene section.

The sedimentation rates (Quilty et al., this volume) vary significantly between the different sites. In the nanno oozes, the sedimentation rate decreases consistently from Site $319(30-40 \mathrm{~m} / \mathrm{m} . \mathrm{y}$.) to Site $320(5-10 \mathrm{~m} / \mathrm{m} . \mathrm{y}$.) to Site $321(4-5 \mathrm{~m} / \mathrm{m} . \mathrm{y}$.$) . Thus the east side of the$ Galapagos Rise (Sites 320 and 321) has lower carbonate sedimentation rates than the west side (Site 319). In the upper clay units, the reverse situation occurs, with the lowest sedimentation rate occurring at Site 319 (2 $\mathrm{m} / \mathrm{m} . \mathrm{y}$.) and significantly higher rates at the sites east of the rise. This variation is probably due to the relative proximity of the cold Humboldt Current, with its greater nutrient supply. By comparing the sections at Sites 320 and 321, it may be possible to trace the influence of the Humboldt Current and determine when the eastward motion of the plate brought those sites under the current's domain. Because the position of the current is presumably controlled by the South American coastline, the sedimentary record may give some information on the relative convergence rates of the Nazca and South American plates in the past.

Figure 4 gives a summary of visual estimates of metalliferous component abundances in the cores from the three sites. Note that metalliferous component abundances up to $15 \%-30 \%$ of the total sediment were observed at each site, though not always at the same age or position in the core. In general, the metalliferous content increases toward the basement, but is not restricted to the basal units. At Site 319, a high abundance occurs near the top, but this appears to be a concentration related to major carbonate dissolution. The actual sedimentation rate of metalliferous components in the top clays at Site 319 is probably similar to or even less than that in the immediately underlying nanno oozes. The higher metal contents in the lower part of the core, however, reflect a production rate (of the particles) that is some 3-5 times higher than in the upper beds. The other two sites do not show any significant amount of metalliferous particles in the top of the core, but show abundances in the lower sections comparable to those at Site 319 (especially when the higher carbonate sedimentation rate at Site 319 is taken into account). Since the lower core sections are of different ages at the three sites, the abundances of metalliferous components appear generally related to proximity to basement (essentially geographic proximity to the spreading ridge). The general absence of metalliferous components in the upper sections at Sites 320 and 321 may be related to the westward jump of the spreading center from the Galapagos Rise to the present East Pacific Rise. The persistence of high metal content for tens of meters above basement and the rather sudden decrease to lower content, shown especially at Sites 319 and 321, imply a more complicated model than that of concentration as a simple inverse function of distance from an active ridge crest. 